\title{
Ascospore discharge by Neofabraea populi, a cortical pathogen on Populus
}

\author{
TIMO KURKELA
}

Kurkela, T. 1997: Ascospore discharge by Neofabraea populi, a cortical pathogen on Populus.- Karstenia 37:19-26. Helsinki. ISSN 0453-3402.

\begin{abstract}
Ascospore production and discharge by Neofabraea populi on hybrid aspen (Populus $\times$ wettsteinii) was studied during two summers in Finland. The main spore production began in July and continued until mid-October. High spore counts were obtained in connection with occasional rain showers from July to September. In the daily data, amount of precipitation, relative humidity, and daily maximum amount of dew correlated positively with the number of spores. Spore release was usually induced by rain, often with several hours delay, as was clearly seen in the short-term hourly variation in the number of spores.
\end{abstract}

Key words: Neofabraea populi, Populus tremuloides, hybrid aspen, Populus $\times$ wettsteinii, Populus tremula $\times$ Populus tremuloides, spore dispersal, spore production, weather factors

Timo Kurkela, Finnish Forest Research Institute, P.O. Box 18, FIN-01301 Vantaa, Finland

\section{Introduction}

Neofabraea populi G.E.Thomps. is an ascomycete which causes cortical necrosis on several aspens and poplars. Thompson (1939) described the fungus on Populus grandidentata Michx., P. tacamahaca Mill. and P. tremuloides Michx. in Ontario, Canada, and later it was reported on several Populus species and hybrids of the sections Leuce, Aigeiros, and Tacamahaca in Japan (Ito et al. 1969). In Norway it injured mostly hybrid aspen $P . \times$ wettsteinii Hämet-Ahti $(P$. tremula L. $\times$ P. tremuloides) (Semb \& Hirvonen-Semb 1968). In reporting the occurrence of the fungus in young hybrid aspen plantations in Norway and Finland in the 1960s, Roll-Hansen and RollHansen (1969) and Langhammer (1971) noted the particular susceptibility of $P$. tremuloides, which had been introduced for experimental purposes. Shortly afterwards Kallio (1972) found the disease in several hybrid aspen stands established in southern Finland. Since then, no reports appears to be published anywhere on this disease or the fungus.
Roll-Hansen and Roll-Hansen (1969) assume that $N$. populi infects hybrid aspen through lenticels. Conidia are produced in autumn and, according to Langhammer (1971), they may be dispersed in water from rain or melting snow running down the stem, finally producing long cankers on the side where the bark surface is drying slowly. Small cankers are also found on branches around the crown, where they may be the result of the airborne dispersal of ascospores. Thompson (1939) and Roll-Hansen and RollHansen (1969) found mature apothecia of $N$. populi in June, July, and August, but the whole range of ascospore production has never been studied.

According to Nannfeldt (1932), the genus Neofabraea H.S.Jacks. is closely related to $\mathrm{Pe}$ zicula Tul. Most of the fungi in these genera have the Cryptosporiopsis conidial state. Pezicula cinnamomea (DC.) Sacc. probably infects oaks through bark lenticels (Kehr 1992), and $P$. malicorticis (H.S.Jacks.) Nannf. infects apple trees through leaf scars, wounds, and lenticels (Viennot-Bourgin 1966; Katschinski \& Ramson 
1975; Senula \& Ficke 1985). P. malicorticis and P. corticola (C.A.Jørg.) Nannf. produce their ascospores during the autumn (Sharples 1962; Daebeler 1966).

The present report describes the period of ascospore production, the release of ascospores, and the dependence of the daily and hourly number of spores on weather conditions.

\section{Materials and Methods}

Production of ascospores of $N$. populi was investigated with spore traps in an aspen stand of selected trees of $P$. tremula and $P$. tremuloides used for breeding purposes in the Ruotsinkylä experimental forest at Tuusula in southern Finland. The approximate height of the stand was 8 $\mathrm{m}$. Spores were trapped in a standing tree in 1973 (I). Some of the infected trees died in 1977 when they were thickly covered with apothecia on the parts of the bark killed by the fungus during the previous growing season. A $2 \mathrm{~m}$ section of a stem $(\varnothing$ about $6 \mathrm{~cm}$ ) was cut and transported to a garden in Helsinki (14 km south of the former location) where spore trapping was repeated in 1977 (II). Temperature, relative humidity, precipitation, and dew were recorded in both places as described by Kurkela (1973). The amount of dew is presented in arbitrary units since the dew gauge did not distinguish between condensed and precipitated water. In the first summer, the spore trapping was begun in May and continued until August 7. In the second summer, the trapping was begun in July, when mature asci were first found in the apothecia, and terminated in October when the apothecia appeared to be empty.

In both summers (I and II), the ascospore source was a long canker completely covered with apothecia, located at the height of $2 \mathrm{~m}$ above the ground (I) on a living stem of P. tremuloides or (II) on a $2 \mathrm{~m}$ long piece of dead stem removed from the growth site. Spores were trapped with a volumetric trap which makes discrete spore prints for adjustable periods (Kurkela 1994). The trap was placed at a height of $2 \mathrm{~m}$ (the first summer) and at a height of $1 \mathrm{~m}$ (the second summer) with the orifice directed horizontally towards the spore source at a distance of 3 $\mathrm{cm}$ from the apothecia. Ascospores were collected on the trap drum surface, which was coated with vaseline, from which the spores were removed with commercial Scotch ${ }^{\circledR}$ tape. The drum was rotated stepwise between the collecting periods. In this study each collecting period was $27 \mathrm{~min}$ plus $3 \mathrm{~min}$ for moving between steps. The tape pieces, each with 12 spore prints, were mounted on microscope slides in Euparal (Kurkela 1994).

The spores were counted from ten fields of view on each separate print under the microscope using a magnification of $10 \times 25$; and the spore size was measured with an image analysis system (Leco 2001). The air flow through the trap orifice was $10 \mathrm{l} \mathrm{h}^{-1}$. Thus the results could be expressed as the number of spores $\mathrm{m}^{-3}$ of air; however, in this study the spore counts were not converted to volumetric values. The hourly sums of the sequential half-hourly spore counts were used in analysing the effect of weather factors on spore discharge.

\section{Results}

\section{Characteristics of ascospores}

The trapped spores had three septa, except for a very few with four to six, and they were always brown in colour, 10-20 × 4-9 $\mu \mathrm{m}$ (Fig. 1).

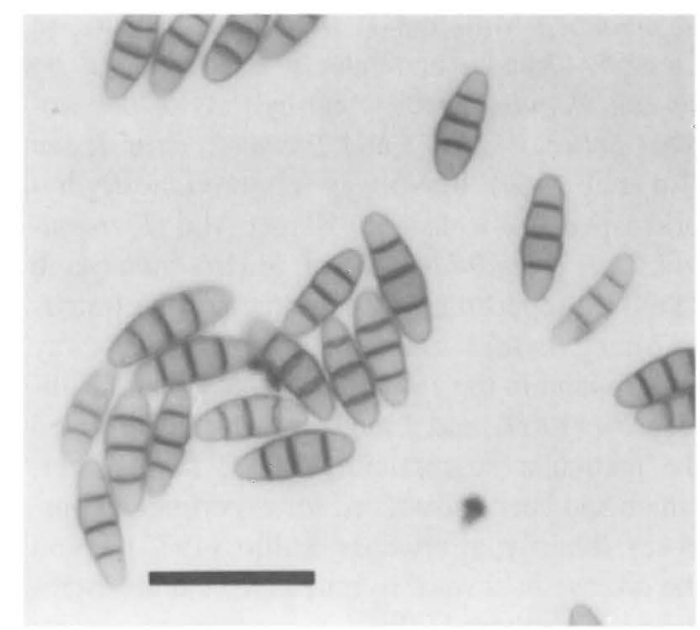

Fig. 1. Four-celled, brown ascospores of Neofabraea populi, scale bar $20 \mu \mathrm{m}$. (Kurkela 1994). 


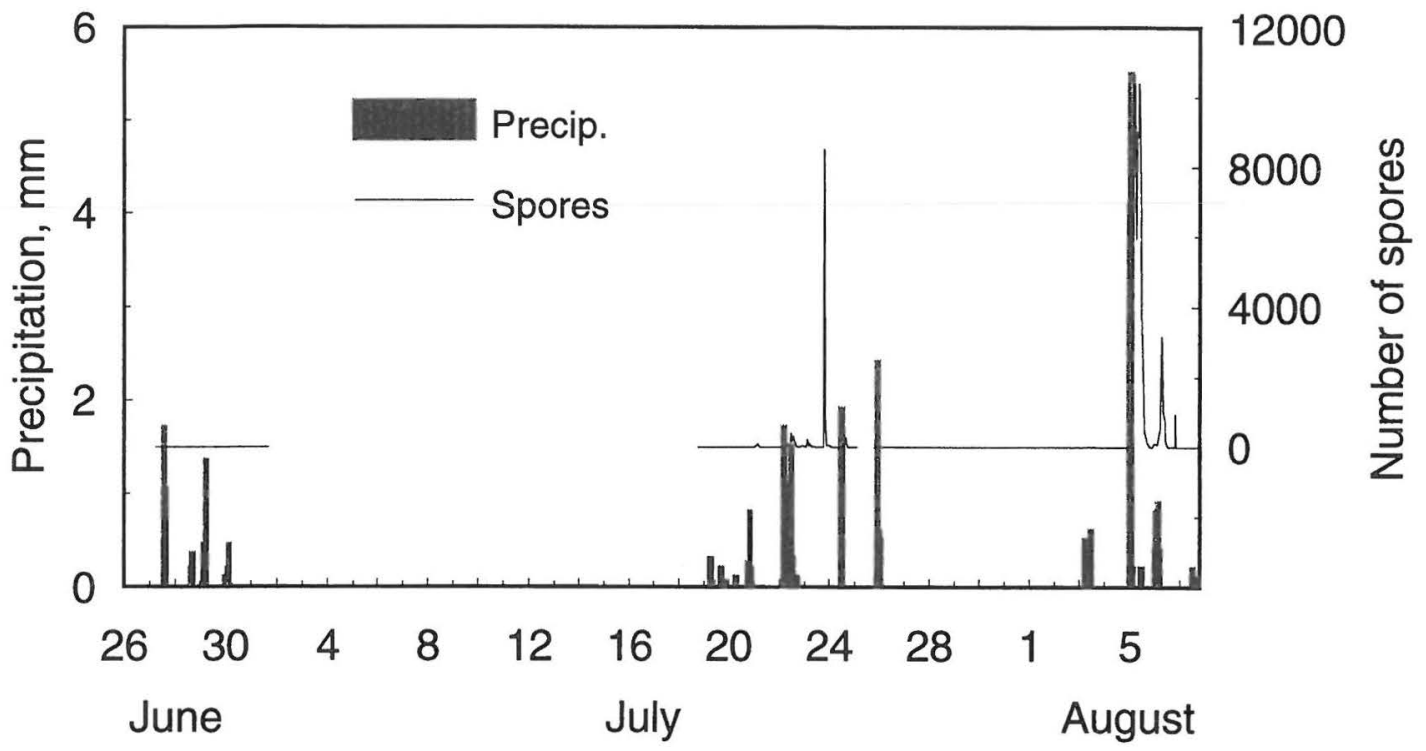

Fig. 2. Ascospore production of Neofabraea populi and amount of precipitation presented as hourly values from June 26 to August 7 (first season, I). To distinguish the line showing the number of spores, broad shaded columns covering about six hours are used for precipitation.

Spore production period

During the first summer (I), some ascospores were found at the end of June (Fig. 2) when apothecia seemed to be mature. These spores were not, however, included in the material for statistical examination, since they were not observed in systematic countings and it is possible that they were background dispersal of similar spores of other fungi. In occasional checks during the rainless period from July 1 to July 18 , no ascospores of $N$. populi were found on the slides. Spore release began on July 21 and a relatively large number of spores $\left(10266 \mathrm{~d}^{-1}\right)$ was obtained on July 23. This peak is difficult to explain since most of the spores $\left(8600 \mathrm{~h}^{-1}\right)$ were obtained at 8 p.m. without any significant change in the recorded weather conditions. However, precipitation during the four previous days $(7.1 \mathrm{~mm})$ may have caused simultaneous maturing of huge numbers of spores. July 27 to August 2 was again a dry period, and only a few sporadic spores were trapped. A new rainy period began on August 3, and the maximum daily number of spores (82 059) was obtained on August 5. The trapping was concluded on August 7, although spore production continued.

In the second summer (II), the trapping began on July 7. The first rain in June occurred on June 10, and the first ascospores were recorded on July 13. After that date rain showers were frequent during the next 18 days, and the maximum daily number of spores (29 615) was obtained on July 19. Throughout the rest of the summer, high daily numbers of spores were obtained only in conjunction with rainy periods (Fig. 3). The last spores were trapped on October 17, when the daily total was 460 . At this time, very few asci in the hymenia contained spores, and most of the trapped spores probably represented previously released spores which had been redispersed by splash water. 

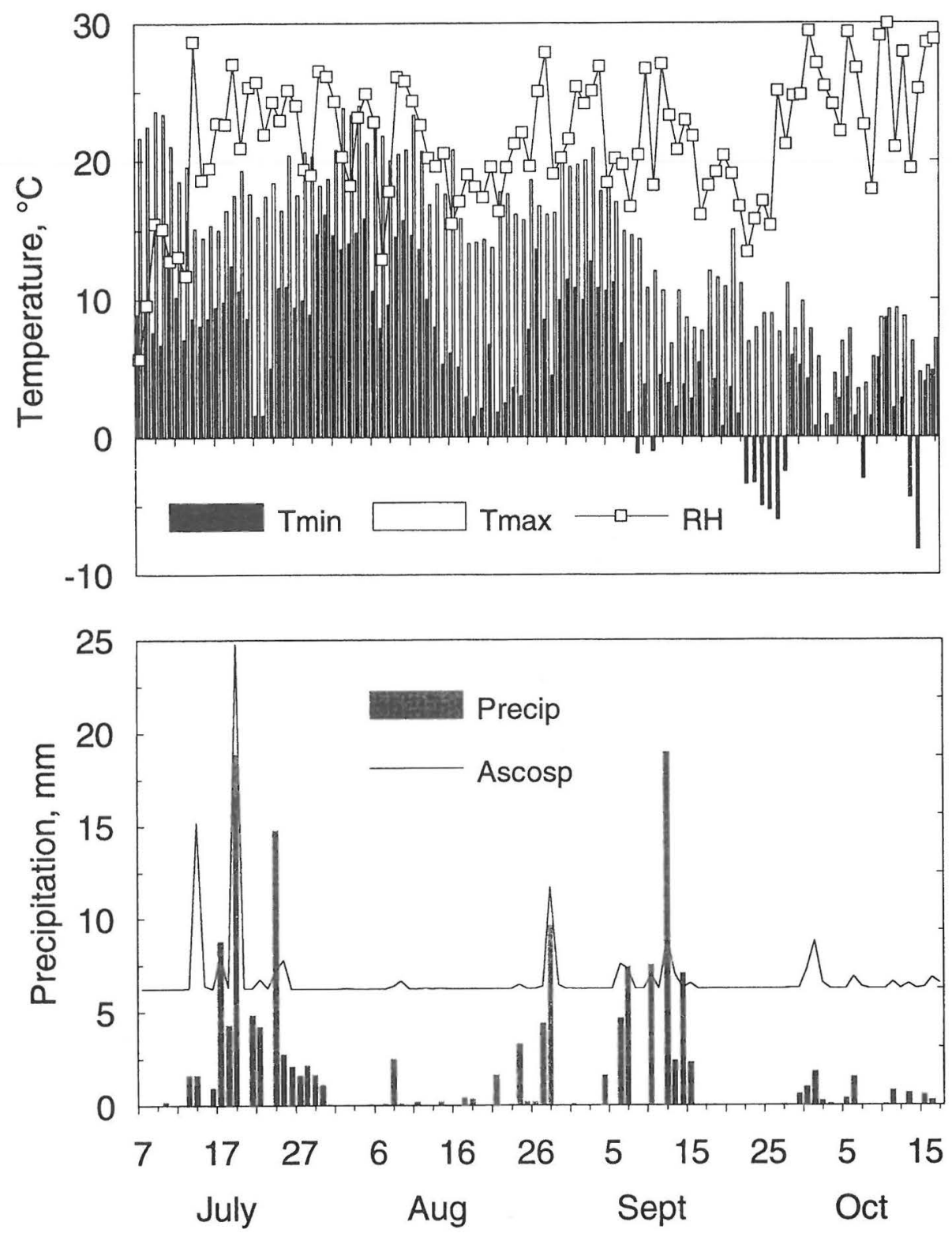

30000

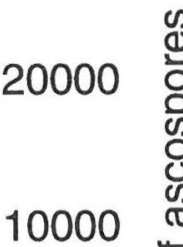

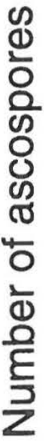

Fig. 3. Daily maximum and minimum temperatures, precipitation, spore production of Neofabraea populi, and relative humidity from July 7 to October 17 (second season, II).

Daily variation in the number of spores

The daily number of spores correlated highly significantly with the amount of precipitation. Relatively high correlations were also obtained with the daily maximum amount of dew and with average relative humidity (Table 1 ). In the analy- sis of variance, daily precipitation was the only weather variable that had a statistically significant effect on the daily sums of spores, $\mathrm{p}<0.01$ (I) and $\mathrm{p}<0.001$ (II). 
Short-term variation in spore discharge

In 1973, the hourly number of spores did not correlate with any weather factor; the maximum correlation coefficient was with dew (Pearson's $\mathrm{r}=0.138$ ). When the weather data was lagged stepwise, the highest correlations between the number of spores and amount of precipitation, relative humidity, and dew were obtained with a lag time of three to four hours. The correlation with the amount of precipitation was relatively high $(\mathrm{p}<0.05)$ at a lag time of 2 to 10 hours, with the maximum correlation at a lag time of four hours $(\mathrm{r}=0.422 * *)$ (Fig. 4). The number of spores correlated significantly with temperature with a delay of 19 hours. In 1977, the number of spores correlated significantly with amount of precipitation at zero lag time $(\mathrm{r}=0.432 * *)$ and at a lag time of one hour ( $\mathrm{r}=0.472 * *)$ (Fig. 4).
Table 1. Correlation of the number of ascospores of Neofabraea populi with the daily values for weather factors during two seasons (I and II). ** $\mathrm{p}<0.01$, * $\mathrm{p}<$ 0.05 .

\begin{tabular}{lll}
\hline & I & \multicolumn{1}{c}{ II } \\
\hline Precipitation, mm & $0.809 * *$ & $0.620^{* *}$ \\
Relative humidity, \% & 0.243 & $0.272^{* *}$ \\
Dew & 0.370 & $0.255^{*}$ \\
Avg. temperature, ${ }^{\circ} \mathrm{C}$ & 0.167 & 0.048 \\
Max. temp. ${ }^{\circ} \mathrm{C}$ & -0.082 & 0.010 \\
Min. temp. ${ }^{\circ} \mathrm{C}$ & 0.430 & 0.133 \\
\hline $\mathrm{N}$ & 17 & 103 \\
\hline
\end{tabular}

Fig. 4. Correlation between the number of ascospores of Neofabraea populi and the amount of precipitation after different lag times.

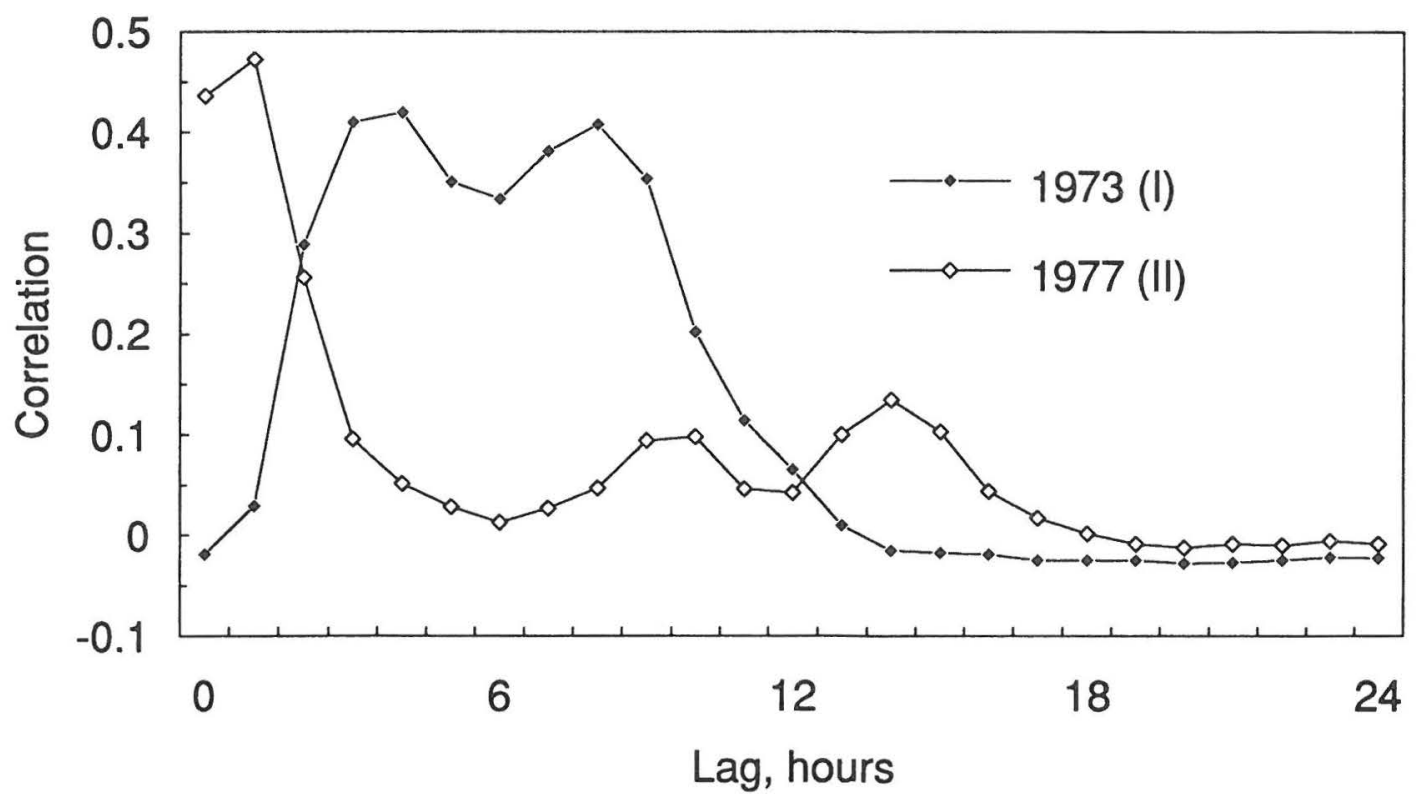

Temperature, relative humidity, and the amount of dew exhibited clearly significant diurnal cycles, while precipitation did not. In the analysis of variance, the lack of statistical significance in the relationship between the number of spores and amount of precipitation at zero lag time in 1973 is reasonable, since high spore releases were induced by short rain showers following long dry periods (Figs. 2 and 5). The fre- quent rain showers in 1977 induced almost immediate spore release (Fig. 6), in an effect that was statistically highly significant $(\mathrm{p}<0.001)$. Apparently, in both years, the effect of precipitation on the spore release was the same, but more frequent rain showers and an c. $15 \%$ higher relative humidity caused a more rapid initiation of spore release in 1977 than in 1973. Regarding humidity, $64 \%$ of spores were trapped when RH 


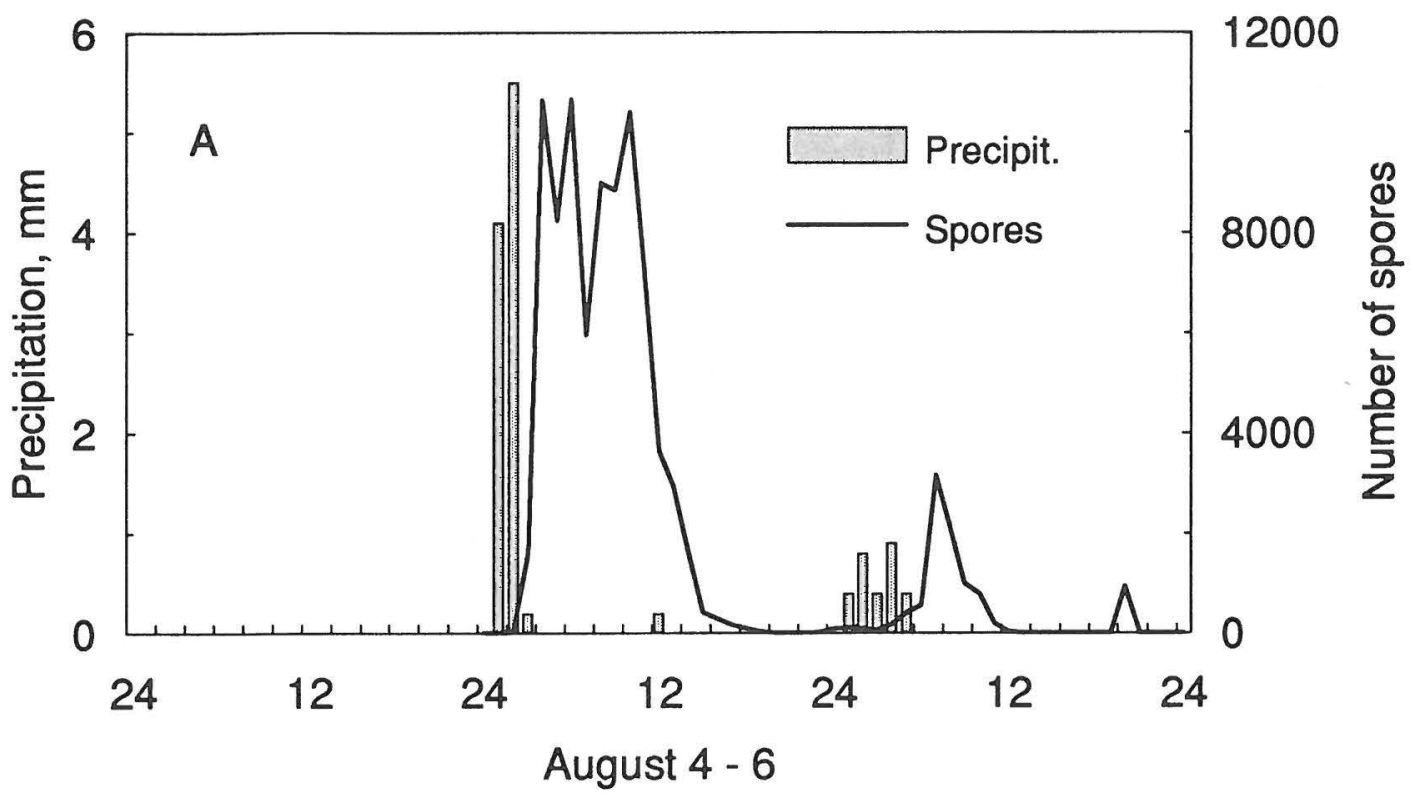

Fig. 5. Relationship between rain showers and hourly spore release, August 4 -6, 1973.

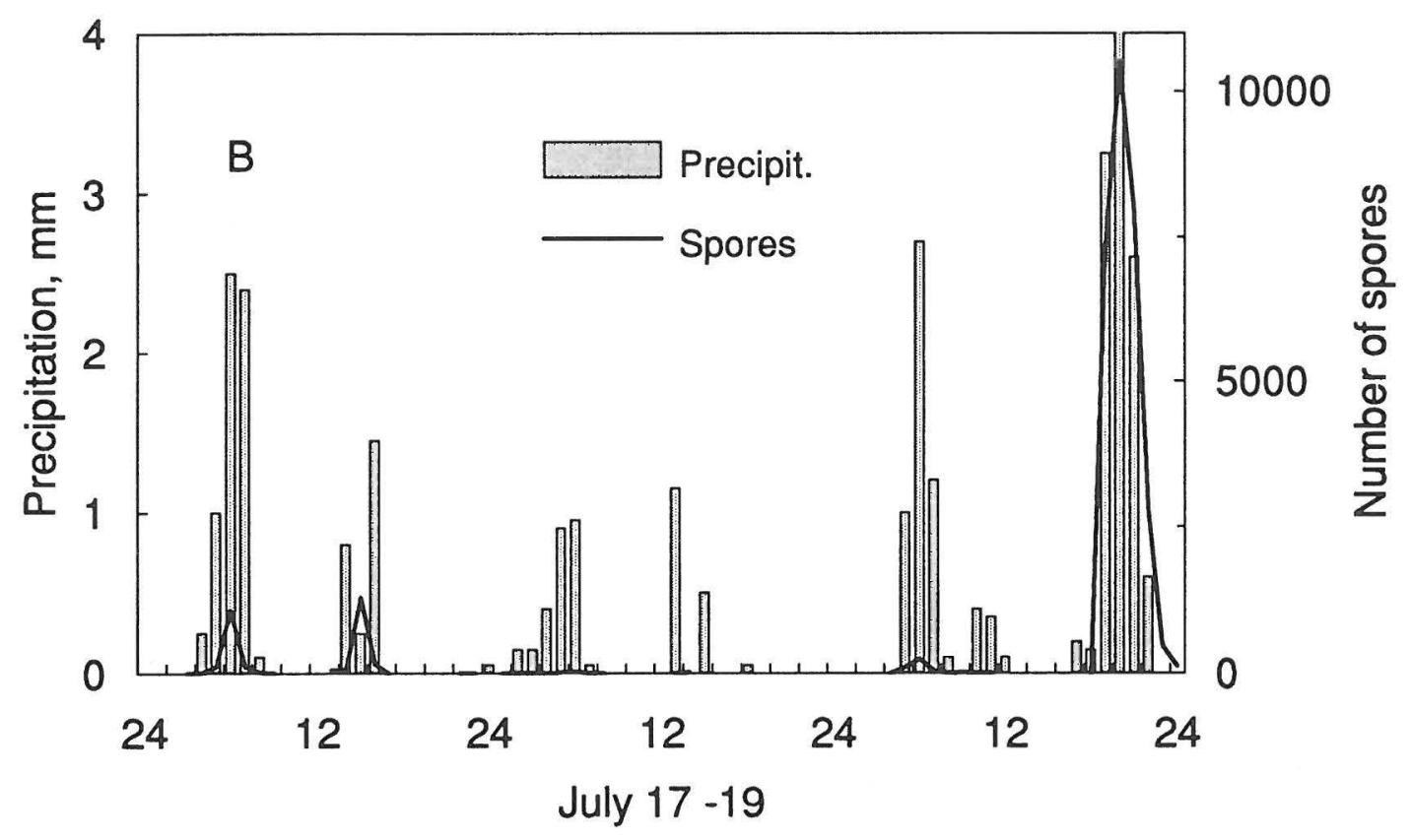

Fig. 6. Relationship between rain showers and hourly spore release, July 17—19, 1977. 


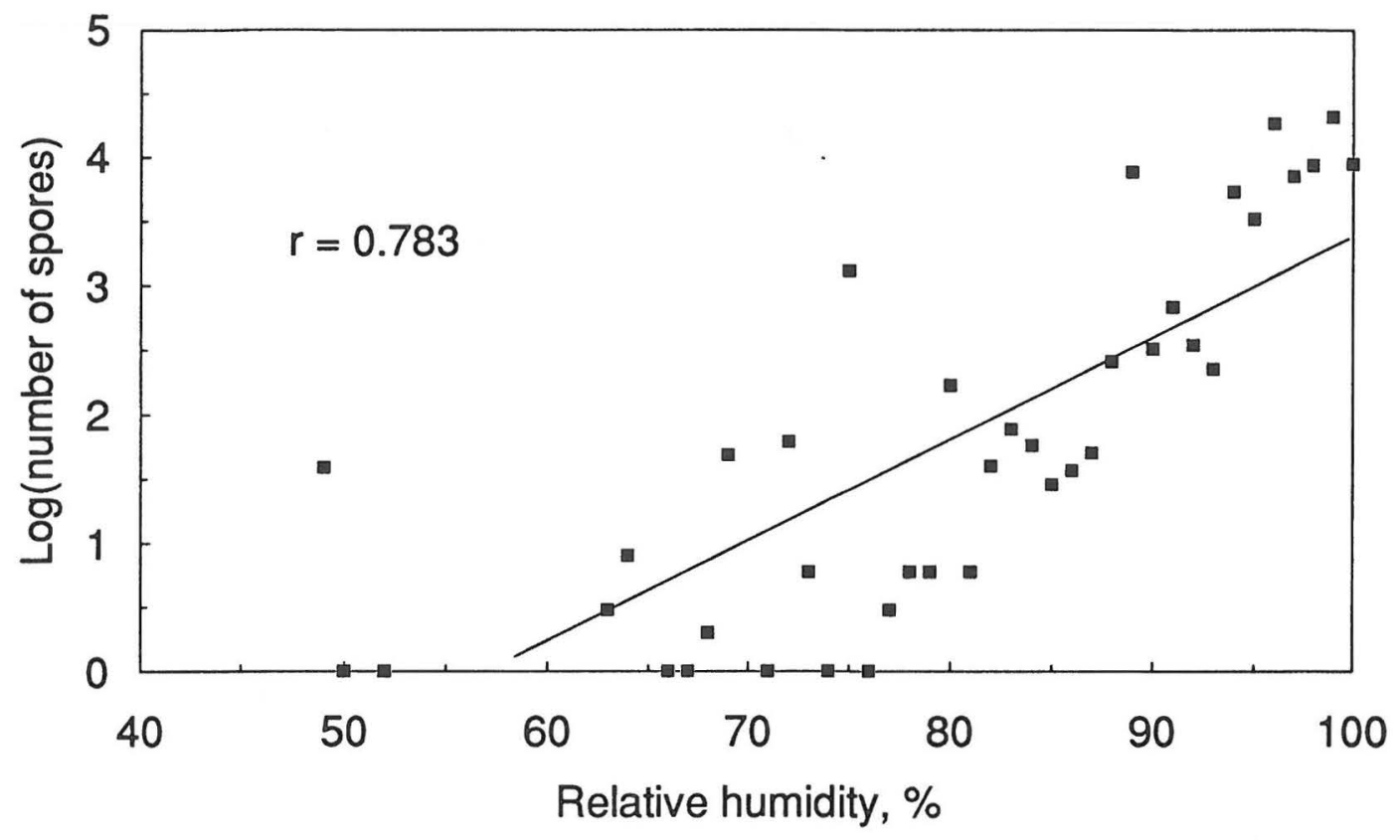

Fig. 7. Relationship bertween relative humidity $(\mathrm{RH})$ and the number of spores obtained at each $\mathrm{RH}$ percentage level (1977).

was $>85 \%$ in 1973 , while more than $97 \%$ of spores were trapped at these high humidity conditions in 1977.

The relationship between spore release and relative humidity was more clearly demonstrated when the logarithmic values of the total number of spores were plotted against the percentage values of $\mathrm{RH}$ at which the spores were obtained (Fig. 7). In this dataset, Pearson's correlations between the number of spores and RH were 0.544 and 0.783 in 1973 and 1977, respectively.

\section{Discussion}

Apparently, during the first summer the onset of spore release was delayed two or three weeks due to the dry period from the end of June to July 21 ; and spore production evidently continued after August 6 when the trapping ceased. In the second summer, the study covered the entire spore production period. The spores were recorded on July 13. It is possible that some of the spores may have been released before the beginning of systematic counting on Jyly 13 , since the first asci in the apothecia must have matured during the rainy period at the end of June. It also seems propable that some redispersal of previously released spores took place after trapping was terminated. According to earlier studies of herbarium specimens (Thompson 1939, RollHansen \& Roll-Hansen 1969), apothecia of $N$. populi mature from June to August. In contrast to this, the results of the present study show that the production and dispersal of ascospores continues at least to mid-October.

The main differences between 1973 and 1977 in the effect of weather factors on the number of spores were as follows: relatively more spores were released in the drier conditions of 1973 than in 1977; in the summer of 1973 spore release was delayed several hours from the beginning of rain, while in 1977 rain and spore release occurred more closely together. The foliage of the experimental tree, still standing in 1973, may have trapped considerable amounts of water during weak showers, thus preventing the immediate wetting of apothecia at the beginning of precipitation. It may also be 
that the fungus required a longer wetting period for the initiation of spore release in 1973 when the weather was dry than in 1977 when the air was constantly humid because of the frequent rain showers. A similar delayed effect of rain on ascospore release has been reported for Venturia inaequalis (Cooke) G.Winter (Aylor \& Sutton 1992) and in Phacidium infestans P.Karst. (Kurkela 1995). The different location of the spore trapping in the two years is unlikely to have caused any differences in the spore production period or the effect of weather conditions.

In earlier papers (Thompson 1939, RollHansen \& Roll-Hansen 1969, and Ito et al. 1969), the ascospores are described as hyaline, and one- to four-celled. Perhaps ascospores which are mature in asci but not yet ready to be released are hyaline. However, the spores trapped in this study were a little wider than in the above-mentioned descriptions; and they were always brown, which may indicate a high resistance to dry conditions. If so, late dispersed ascospores might well be able to participate in the infection process simultaneously with conidia, which are known to develop in acervuli in late autumn (Roll-Hansen \& Roll-Hansen 1969).

Acknowledgements. The author is indebted to Dr. Larry Huldén who, as a student at the time, counted all the spore material with great patience. Thanks are also due to Dr. Kari Korhonen for his constructive comments on an early draft of the manuscript. The English of the text was revised by Dr. Kathleen Ahonen.

\section{References}

Aylor, D.E. \& Sutton, T.B. 1992: Release of Venturia inaequalis ascospores during unsteady rain: relationship to spore transport and deposition. - Phytopathology 82:532-540.

Daebeler, F. 1966: Untersuchungen über die Umweltsabhängigkeit des Auftretens von Cryptosporiopsis corticola (Edg.) Nannf. an Kernobstbäumen in Mecklenburg. - Wissensch. Zeitschr. Univ. Rostock, math.-naturwissensch. Reihe 15:229-237.

Ito, K., Chiba, O. \& Kondo, H. 1969: Neofabraea canker of poplars in Japan. - Bull. Govt. Exp. Station Meguro 225:31-40 (in Japanese with English summary).
Kallio, T. 1972: Erään 10-vuotiaan hybridihaapametsikön lahovikaisuus. Summary: Decay in a tenyear-old stand of hybrid aspen. - Silva Fennica $6: 1-13$.

Katschinski, K.-H. \& Ramson, A. 1975: Beitrag zur Biologie und Bekämpfung von Gloeosporium-Fäulen an Äpfeln. - Nachrichtenblatt Pflanzenschutz DDR 29:168-172.

Kehr, R.D. 1992: Pezicula canker of Quercus rubra L., caused by Pezicula cinnamomea (DC.) Sacc. II. Morphology and biology of the causal agent. Eur. J. Forest Pathol. 22:29-40.

Kurkela, T. 1973: Epiphytology of Melampsora rusts of Scots pine (Pinus sylvestris L.) and aspen (Populus tremula L.). - Commun. Inst. Forest Fenniae 79(4):1-68.

Kurkela, T. 1994: A sampler making discrete spore prints, useful for spore release studies. - Karstenia 34:61-64.

Kurkela, T.T. 1995: Short-term variation in ascospore release by Phacidium infestans on the needles of Pinus sylvestris. - Eur. J. Forest Pathol. 25:274 281.

Langhammer, A. 1971: Neofabraea populi in plantations of hybrid aspen in Norway. - Medd. Norske Skogforsøksv. 29:81-91.

Nannfeldt, J.A. 1932: Studien über die Morphologie und Systematik der nicht-lichenisierten inoperculaten Discomyceten. - Nova Acta Regiae Soc. Sci. Upsaliensis, ser. 4, 8(2):1-368.

Roll-Hansen, F. \& Roll-Hansen, H. 1969: Neofabraea populi on Populus tremula $\times$ Populus tremuloides in Norway. Comparison with the conidial state of Neofabraea malicorticis. - Medd. Norske Skogforsøksv. 22:215-226.

Semb, L. \& Hirvonen-Semb, A. 1968: Poppel-barkbrann en ny soppsjukdom i Norge. - Gartneryrket 58:582-583.

Senula, A. \& Ficke, W. 1985: Untersuchungen zur Pathogenese des Gloeosporium-Rindenbrandes. Arch. Phytopathol. Pflanzenschutz 21:185-198.

Thompson, G.E. 1939: A canker disease of poplars caused a new species of Neofabraea. - Mycologia 31:455-465.

Viennot-Bourgin, G. 1966: Les pourritures lenticellaires des fruits a pépins. - Israel J. Bot. 15:182-191.

Received on 30 January 1996 